\title{
Analysis of Interest Rate Impact on the Profitability Level of the Banking System in Albania during the Period $2005-2014$.
}

\author{
Sokol NDOKA, PhD Candidate
}

Prof. As. Dr. Anilda BOZDO

\begin{abstract}
This study is an analysis of the movement and impact of interest rates on the profitability level of the banking system in Albania. This analysis covers a 10-year timeframe (is organized in three time segments - before, during and after the financial crisis), taking into consideration the critical point of the years 2008-2009 considered as the "peak" of the global financial crisis. Such separation is made in order to see the possible changes of each period of time and to identify the impact differences of this factor in each period of study. This study is based on the hypothesis that the decrease of the interest rate has positively affected the income increase from interest as a result of the impact of two factors, negative levels of Gaps and an increased level of spread toward the average assets. As a matter of fact, it has neutralized on a certain level the other risks such as that of the loan which has dominated over the other risks. This paper is based on an empirical study with secondary quantitative and qualitative data. This study provides a considerable contribution in the framework of identification of factors affecting the profitability of the banking system in Albania, namely in the context of interest rate; In addition, this study aims at highlighting the importance of open Gaps minimization for the efficient profitability increase of the financial system.
\end{abstract}

Key words: Albanian banking system, profitability, interest rate risk, Gaps, spreads, movement, global financial crisis.

\section{1-Introduction}

In nowadays business impact plays a critical role. Almost in every business decision it is required to the managers and executives to balance impact with return. The effective management of business impact is essential to the success of the company. In the banking system the impact management takes a special importance. Some of the main impacts that directly affect the profitability of commercial banks are:

Interest rate impact,

Credit impact,

Operational impact,

Exchange rate impact.

\section{The aims and objectives of the study:}

1- $\quad$ The analysis of interest rate impact in relation to the profitability of commercial banks in Albania during the period 2005-2014.

2- $\quad$ The compilation of a report that shows the current situation of the profitability of commercial banks in Albania in connection with interest rate impact.

\section{Hypotheses of the work:}

The interest rate impact is one of the main factors affecting the profitability of commercial banks in Albania during the period 2005-2014. 


\section{Research question:}

1. How has the interest rate impact affected on the financial result of the commercial banks in the period 2005$2014 ?$

2. Did the commercial banks Albanian keep the reprising gaps at critical levels?

\section{Working methodology:}

Qualitative approach (qualitative data), quantitative approaches (quantitative data).

\section{2-The interest rates and their impact}

The interest rates are among the most monitored indicators in an economy because of the self importance that they have. Basically, the interest rates represent the cost of borrowing, so the price of credit and as such they affect both the personal, family and business everyday decision making as well as the economic development of the country. When the real interest rates are low in an economy are encouraged the investments and borrowings while when the real interest rates are high we have a contraction of the credit's delivery as funds become more costly. The impact arising from changing interest rates called differently interest rate impact represents the impact that the interest rate changes cause additional costs for the banking sector and affect negatively the net incomes from interest and the net value of bank capital. In the balance of commercial banks more than $50 \%$ of the total income derived from interest income and this makes banks more exposed to the interest rate impact and therefore the ALM managers pay particular attention that in order this impact does not affect the performance of banking activity. The interest rate impact is increased in recent years as a consequence of the international financial crisis and with the aim of identifying and reducing this impact in a timely manner by banks and branches of foreign banks that operate in Albania, the Bank of Albania in April 2013 has issued an instruction "On the administration of the interest rate impact in the bank's book" in which are determined the basic requirements and regulations for the management of interest rate impact in the bank's book, the method of calculation of the exposure towards the interest rate impact as well as reporting to the Bank of Albania.

\section{1- Sources and effects of interest rate impact.}

The interest rate impact may derive from various factors and among the most important are: reprising impact, yield curve impact, basic impact and options' impact. Reprising impact is one of the impacts that commercial banks face more often. This impact arises from the difference in maturity between assets and liabilities with fixed interest rates and from the reprising of bank assets and liabilities with changeable interest rates and makes that an interest rate change brings unequal changes between the assets and liabilities and net income from interest by exposing the bank to interest rate impact. The discrepancy between the maturities of the portfolio of a bank may refer it to the yield curve impact. This impact arises when unexpected changes to the shape and inclination of the yield curve affect negatively the bank incomes or the market value of banking capital. The basic impact arises when the interest rates imposed on loans and the interest rates placed on deposits for the same maturities are not assigned to such levels that the bank can realize profits and a change of interest rate can bring it a significant spread between incomes and expenses for interest resulting in financial losses. The options' impact arises when the bank owns sensitive options toward the interest rate, these options may be related to securities or not. The change of the interest rates of these options exposes the net income toward the interest rate impact bringing losses to the bank. As also mentioned above, the interest rate fluctuation affects the net income from interest and the economic value of the bank. These two indicators serve to the bank for the assessment of exposure to interest rate impact. The income analysis considers the impact of interest rates change on the realized incomes. This analysis is used by almost all banks because incomes of the bank have a great importance for the bank, the reduction of incomes or the bank losses could threaten the financial stability of the bank and the capital value. The income analysis is divided into two parts, the first part analyzes the relationship of net income from interest to total income and directly sees the connection between the interest rate changes and the income from them and the second part analyzes the relationship between the incomes 
generated by other activities to the total income as the interest rates change also affects to the latter, although not directly. The analysis of the economic value of the bank serves mostly to the shareholders and managers of the bank to assess the net capital value since the economic value takes into account the potential impact of interest rates change on the present value of cash flow that in future shows a clearer picture of the impact of the interest rate change on a long-term period.

\section{2- The management models of interest rate impact.}

The rapid development of financial institutions has meant that banks are more exposed to interest rate impact and to protect against its they use various techniques and statistical models. Below will be treated the reprising model, which is based on the gap between sensitive assets and liabilities, maturity mode/ which is based on the maturity gap and the duration model which is based on the duration gap. These models show the effect of interest rate change to the market value of the bank's assets and liabilities and to net income from interest.

\section{3- Econometric model on net margin of the interest rates}

\section{1- Net interest margin}

Net interest margin is the most appropriate indicator of efficiency and suitability assessment of the activity of a bank or a banking system in general. This indicator measures the efficiency of the management of bank assets that generate income for the bank and serves as the main criterion in the optimization of banking assets' structure. The net interest margin (NIM) is calculated as the ratio between net income from interest and average total assets or between net income from interest and income generating assets.

This indicator in the banking system has had oscillations, in 2005 was its lower level, up to its maximal increase its 2007, a year when had not yet begun to feel the effects of the economic crisis. 2007 was the boom of the loan portfolio increase by about $78 \%$, which influenced the increase in net interest margin. In 2008 it began the contraction of new credit/loan issues, which led to the reduction of the margin until 2013. Maintaining high levels of spread by the side of the Albanian commercial banks neutralized somewhat the losses from problematic loans.

Chart No. 1 Net interest margin

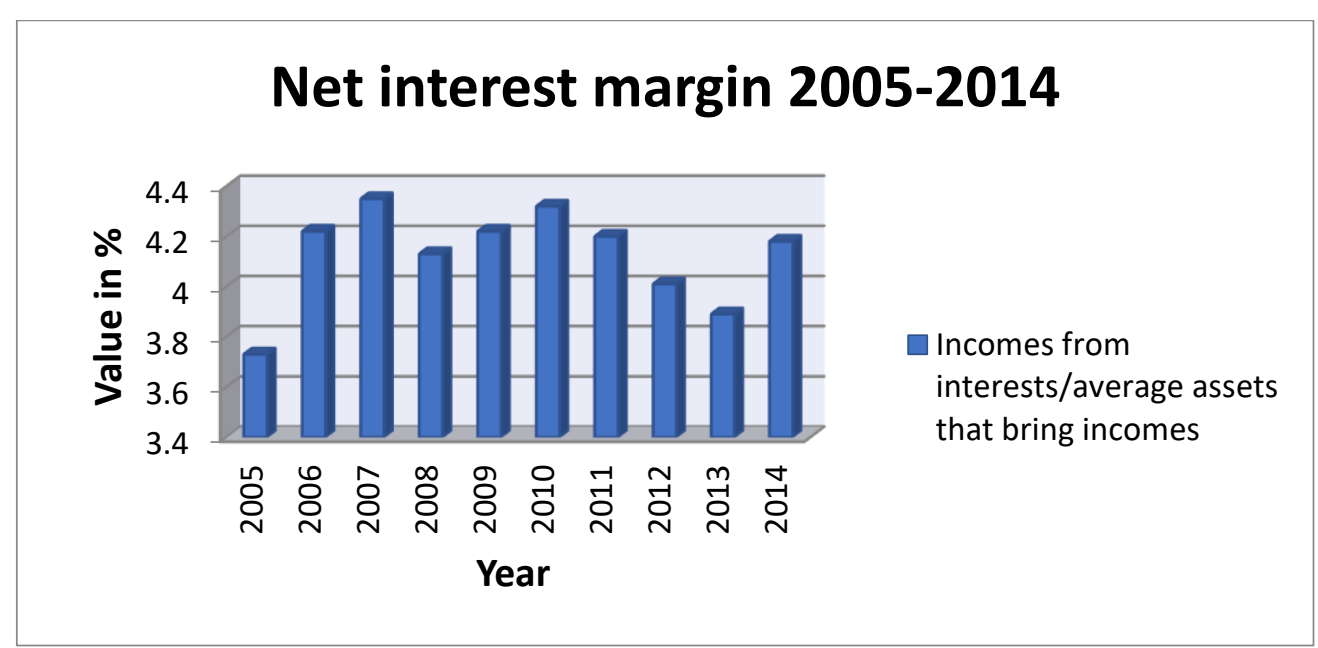




\section{Source: Bank of Albania}

Meantime, keeping the negative gaps by the side of banks as all loans were given with variable interest rate annually, helped to reduce the margin decline, in terms of interest rates declining in unison with the policy followed by the Central Bank European. In 2014 began the expansion of the loan portfolio with new loans, the decline of problematic loans' indicator toward / total loans, which led to increase of net interest margin.

Chart No. 2 The level of gaps according to the intervals of time

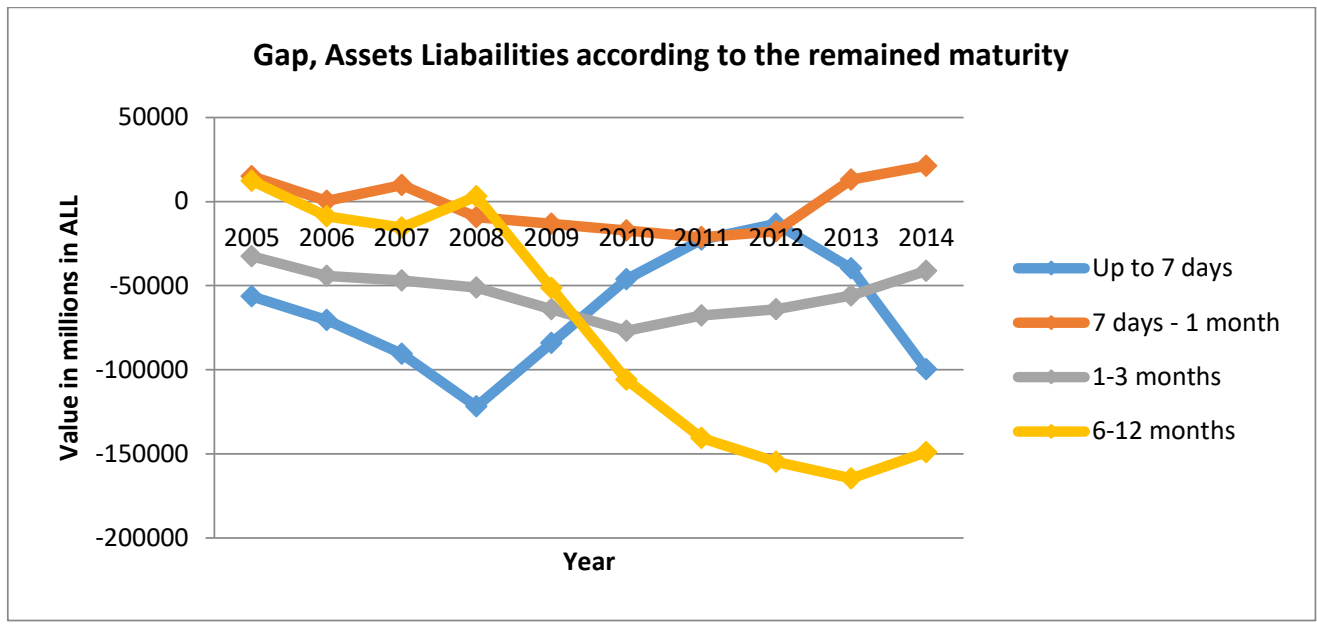

Source: Bank of Albania

MNI fluctuation can come from the change of net income from interest as well as from the level of assets that generate incomes. High levels of net margins may not always show high levels of efficiency but also the opposite, instead that the bank manages the bank impacts it is "protected" by maintaining high interest rates on loans and low interest rates on deposits thus increasing the net incomes from interest. On the other hand, even its reduction doesn't shows efficiency, if we take into account the accounting analysis of net interest margin the reduction of net interest margin may arise from the tax rate reduction or by the increase of credit/loan default. MNI reduction in the first case can bring increased efficiency of the bank or banking system while in the second case, the increase of problematic loans' number can lead to the reduction of the bank's profits. Identification, monitoring and evaluation of the factors that affect the level of net interest margin is very important for policy makers in order to orient their policies for individual banks or the banking system toward its goodfunctioning and stability.

\section{2- The determinants of net interest margin}

There are two methods to measure the net interest margin, the method ex-ante and the ex-post one. Ex-ante method measures the net interest margin before the realization of interest income while ex-post methods are realized as interest income. According to ex-ante method the net interest margin is calculated as the difference between interest rates on loans and deposits specified in the initial contract signed by the bank and customers. These rates can be viewed by the public and are easily comparable between banks. Ex-post method calculates the net interest margin as the difference of incomes and expenses interest that the bank has realized during the study therefore after their realization. The difference between these two methods of measuring the MNI is related to the level of problematic loans. Ex-ante method often produces incorrect results when the source of the applied data can be different, while the ex-post method has several disadvantages because according to Demirguc-Kunt and Huizinga (1998) the incomes from interests and from the reserves created for problematic loans materialize in different time periods. 
From the several empirical studies on net interest margin, the most used methods is the second one, ex-post, since its results are more accurate. According to Demirguc-Kunt (1999), the ex-post method is more inclusive and useful because it takes into account that the banks with higher interest rates and with a high level of loans are potentially more at risk toward the banking impacts. In the study we have reviewed the ex-post method for the measurement of net interest margin, based on data from the financial statements of commercial banks in Albania for the period 2005-2014.

The analysis of factors affecting the level of net interest margin at a commercial bank or banking system is treated according to two methods. The first method is a method of accounting analysis of the net interest margin, while the second method is based on the theoretical treatment of factors affecting MNI which are then applied in practice through econometric analysis. Both of these methods will be treated below.

\section{2. 1- Theoretical analysis of factors affecting the net interest margin}

The pioneer of theoretical analysis of factors affecting the net interest margin is the study of Ho and Saunders (1981) and it was named model of mediation. According to this model, banks are considered as impact-averse agents that collect deposits and give loans, the latter arrive in the bank randomly and where the probability of their arrival depends on the margins that the banks charge and from the elasticity of the demand for loans and of the offer for deposits. The fact that the arrival of deposits and loans is completely random and not in synchrony, exposes the banks toward the interest rate impact. For example, in the case when the bank accepts a deposit but on the other hand there is no demand for a loan, then these funds will be invested in the money market. This case exposes the bank toward the reinvestment impact, the impact that the income from the funds to be reinvested will reduce more than the cost of funds. In case the bank accepts a request for a loan but this loan is financed from the money market and not from the deposits, the bank will be exposed toward refinancing rate impact and credit default impact. The refinancing impact brings that the cost of re-borrowed funds will be higher than the income generated from the investments in assets. To reduce these impacts, in exchange, the banks seek higher margin. Ho and Saunders (1981) in their work argue that banks, in order to increase the shareholder returns impose additional margin (mark-up) for loans and reduced margins (markdown) for deposits in order to minimize the impact of excess (balance) in the demand for deposits or in the offer for credit/loan. According to Ho and Saunders (1981) these established margins, theoretically will depend on four factors: the attitude of the banks towards impact, the market structure where banking institutions are operating, the average size of transactions that the banks realize and the interest rate fluctuation. According to them, even if the banks operate in a market with high competition market, the interest margin will be positive again because it cannot disappear because the bank transactions are always accompanied by insecurity and this margin that emerged from insecurity of the performed transactions is called "pure margin interest" and is supposed to be universal for all banks. The model of Ho and Saunders (1981) uses a two-stage procedure for econometric evaluation of the relative impact of specific micro and macro factors to the interest rate margin. The first stage coincides with the determination of the size of "clean margins" by presenting the effect of explanatory variables that are not explicitly stated in the theoretical model and the second phase coincides with the analysis of the relationship between "pure margins" and the variables presented in theoretical model. According to Ho and Saunders, banks are seen as mediators that accept deposits and give loans passively, so the prices of loans and deposits $\left(\mathrm{P}_{L}\right.$ dhe $\left.\mathrm{PD}_{\mathrm{D}}\right)$ are placed by banks while their quantity is placed exogenously. So

$P_{L}=p-b$ and $P_{D}=p+a$

Where $\boldsymbol{p}$ - indicates the "real" price of the loan or deposit according to the bank, or indicates a margin for the provision of liquidity service speed while $\boldsymbol{b}$ indicates the impact premium for the compensation of the impact arising from the incompatibility of deposits and loans. Prices and interest rates of loans and deposits are inversely related between them, so we can say that: : $r_{D}=r-a$ and $r_{L}=r+b$ where, $r_{D}$ and $r_{L}$ are the interest rates of loans and deposits set by the bank while $r$ is the interest rate in the money market. Thus, the interest margin is calculated as follows:

$S=r L-r D=a+b$

According to the authors, after a series of transformations, the basic equation is expressed as follows:

$s=r_{L}-r_{D}=\alpha / \beta+1 / 2 \times R \sigma^{2} Q$ 
Where, $\alpha$ / $\beta$ indicates the neutral spread of impact, in the conditions of a competitive market $\boldsymbol{\alpha}$ and $\boldsymbol{\beta}$ express respectively the intersection with the vertical axis and the inclination of the symmetric function of the arrival of deposits and loans. $\boldsymbol{R}$ indicates the coefficient behavior toward impact, $\boldsymbol{\sigma}^{2}$ indicates the variance of fluctuations in interest rates for deposits and loans and $Q$ indicates the size of the performed banking transactions.

During subsequent years, several authors used the model of Ho and Saunders (1981), taking as the explanatory variables of net interest margin, besides the theoretical model variables, other variables too. Allen (1988) took into account the provision (offering) of various types of deposits and loans from banks and showed in his study that "pure interest margin" can be reduced as a result of the diversification of products and services offered by banks. McShane and Sharpe (1985) replaced the fluctuation of interest rates on deposits and loans, as in Ho and Saunders, with the fluctuation of market interest rates. Carbo and Rodriguez (2007) developed the model of Ho and Saunders including both traditional and nontraditional activities of the banks aiming the study of the effect of specialization in the banking spread by using the model of the European banking system. Maudos and Fernandez de Guevara (2004) extended the model of Ho and Saunders studying explicitly the bank's operating expenses.

The empirical studies performed on the net interest margin are numerous, such as those on certain countries or groups of countries as well as for individual banks or for the banking system as a whole. The two-stage mediation model that was used by Ho and Saunders (1981) and later by Saunders and Schumacher (2000), requires long time series of explanatory variables of "pure interest margin", but many authors (Demirguc-Kunt and Huizing 1998; Moore and Craugwell 2000; Brock and Rojas-Suarez 2000; Gelos 2006) have also studied the one-stage model which can be realized even with shorter time series and by placing additional variables such as macroeconomic conditions, taxation, regulations on insurance deposits and the structure of financial system to see their impact on the interest margin. The results obtained from numerous studies of $\mathrm{MNI}$ factors are different and in some cases contradictory. Some of the determining factors of net interest margin according to econometric analysis are: the operating costs, the quality management, the credit impact, the liquidity impact, the interest rate impact, the size of banks, the level of capitalization, the non-interest incomes.

\section{4- Specification of econometric model}

The mediation model of Ho and Saunders (1981), later used by Saunders and Schumacher (2000), Estrada et al (2006) and some other authors, assesses the factors which affect the interest margin by following two stages and also It requires long time series. While other authors as Angbazo (1997) and Maudos of Fernandez de Guevara (2004) have applied the one-stage model for determining the factors that affect the net interest margin. Irini Kalluci model (2010) on which my study is based, assesses the determinants of net interest margin by one-stage model applied by Maudos of Fernandez de Guevara (2004) and unlike the latter, the one which identifies the determinants of net interest margin for the 5 countries of the European Union, the model in which my study is based, assesses the factors affecting the net interest margin only for the Albanian banking system for the period 2002-2007 through the method of Panel Data for individual banks as well as model of Fernandez Maudos de Guevara. The model that we'll examine, analyzes the factors affecting only the net interest margin for the Albanian banking system for the period January 2005 - December 2014 for the Albanian banking system. Regarding the dependent variable in our work, unlike Maudos and Fernandez de Guevara (2004) study, in our study as well as in the study of Irini Kalluci (2010), the net interest margin is calculated as the ratio between the net incomes from interests with the assets that generate incomes. The model used in the case of the Albanian banking system differs from the model used by Maudos of Fernandez de Guevara (2004) as the small number of observations does not allow the use of a large number of variables. Differently from the study of Maudos and Fernandez de Guevara (2004), the study of Irini Kalluci (2010) does not include the variable equation that expresses the degree of interaction between credit impact and market impact since they are specifically included in the model and variable that expresses the average size of transactions measured by the volume of loans granted. To measure the market power of banks in the study of Maudos of Fernandez de Guevara (2004) is used the Lerner index and that of Herfindahl-Hirschman while in the case of Albania is used only the latter for reasons of lack of data in the calculation of Lerner index. The market impact is measured by the authors Maudos of Fernandez de Guevara (2004) with the fluctuation of interest rates of the interbank market or of the public debt, while in the case of Albania the market impact is measured as the standard deviation of interest rates on treasury bills, euribor and libor. According to the model in which I am based, for the assessment of the factors that affect the net interest margin will be used eight variables, based on a theoretical model as well as numerous empirical studies. These variables are the 
operating costs, the attitude towards impact, credit impact, which management, opportunity costs of obligatory reserves, non-interest incomes, index of concentration and market impact.

Operating Expenses - This variable is calculated as the ratio between the bank operating expenses and total assets and it's expected that the relationship between the net interest margin and operating expenses be positive. The reason why this indicator is included in the equation is to see if the banks, for high operational cost, transferring the latter to customers by placing higher interest margins or not.

Attitude towards impact - This variable is measured by the ratio between the share capital and total assets and it's expected that its impact on net interest margin be positive as the well-capitalized banks are inclined to establish high margins to protect their capital but is the important to identify the sources of well-capitalized banks. A high level of capitalization of banks not always comes as a result of increasing the share capital of the bank to be more protected from the impacts but it can also come as a result of the regulatory and supervisory requirements by the central bank.

Credit Impact - This variable is measured by the ratio between the problematic loans and the total loans granted and it is expect that this indicator will have a positive impact on net interest margin, the greater this impact will be the greater will be the margin placed on interest rates of loans and new deposits. So in a certain way, the pledge of problematic loans will affect new borrowers.

Quality of management - This variable is measured by the ratio between the operating expenses and its gross income. With quality management we'll mean the identification of low impact assets and high return and of low cost liabilities. The relationship between net interest margin and the quality of management is expected to be negative, the higher will be the ratio of the activity expenses with the gross income, so the management quality will be lower, consequently the lower will be the net interest margin.

Opportunity cost of obligatory reserves - This variable in the case of Albania is calculated as the ratio of obligatory reserves in the central bank toward the total assets unlike the model of Maudos and Fernandez de Guevara (2004) which is calculated as the ratio of liquid reserves with the total of assets. It is expected that the relationship between this indicator and the net interest margin be positive as a high level of reserves would make banks set high interest rates on loans and lower one for deposit aiming the compensation of the loss of profits from the investment of funds in the form of obligatory reserve.

Non-interest income - This variable is calculated as the ratio between the net commission income and the amount of net income from interest and other activities. This variable is expected to have a negative association with the net interest margin as those banks that provide higher income from commissions tend to lower the interest rates on loans and deposits resulting in the reduction of the net interest margin.

Concentration Index - This variable serves as a measure of the degree of concentration in the market in terms of loans. In the case of Albania, this variable is measured by the Herfindahl-Hirschman Index (HHI) and is calculated as the sum of the squares of the market share of credit to any bank in the market. It is expected that a high level of concentration index can lead to higher margins in interest because banks have more power in setting interest rates. But it can also happen that a high level of concentration lead to increased efficiency (cost reduction) and consequently to lower interest margins.

Interest rate impact - This variable is measured by interest rate fluctuation. In the case of Albania, this variable is calculated as the standard deviation of monthly treasury bills rates when during a month has been realized more than one auction, in the contrary has been taken the interest rate of the treasury bills of Bank of Albania's auctions. While for the interest rates of Euribor and Libor were taken into study the monthly interest rates. These two variables have been taken in the study since the loans granted in foreign currencies occupy a significant portion of loans in the entire system. In the model will be treated the three upper variables, taken separately, to identify those interest rates which affect more the net interest margin.

\section{1- The data and assessment methods}

The data used in this study have been obtained from the Bank of Albania and other international institutions. The data used in the model are the monthly data for the entire Albanian banking system for the period January 2005 - December 2014. The dependent variable, the net interest margin, shall be calculated as the ratio between the net income from interest and 
the total assets that generate income. The total number of explanatory variables of the net interest margin (dependent variable) will be 8 and the assessment of the regression equation will be done using the method of least squares (LS). The total number of observations used in the model is 48 and the data are structured.

\section{2- Results of econometric model}

\section{The overall regression equation would appear as follows:}

$$
M N I_{n}=\beta_{0}+\beta_{1} \times X_{1}+\beta_{2} \times X_{2}+\beta_{3} \times X_{3}+\beta_{4} \times X_{4}+\beta_{5} \times X_{5}+\beta_{6} \times X_{6}+\beta_{7} \times X_{7}+\beta_{8} \times X_{8}
$$

Where, $\mathbf{n}$ - indicates the number of the equation in the table below, respectively: 1 for the dependent variable "market impact" measured by the standard deviation of the interest rates of treasury bills when during a month has been realized more than an auction, in the contrary has been taken the interest rate of treasury bills of the Bank of Albania auctions, 2 when this variable is measured by Euribor interest rates and 3 when this variable is measured by Libor interest rate. $\beta_{0}$ indicates the constant, the average value of the dependent variable if all the independent variables are $0 . \beta 1, \beta 2, \beta 3, \beta 4$, $\beta 5, \beta 6, \beta 7, \beta 8$ - indicate the angular coefficient, the estimated differences in the dependent variable with $\beta x$ unit for every one unit of change in the independent variable. $\boldsymbol{X} \mathbf{1}$ - indicates the independent variable - the operating costs, $\boldsymbol{X} \mathbf{2}$-indicates the independent variable - the attitude towards impact, $\boldsymbol{X} \mathbf{3}$ - indicates the independent variable - the credit impact, $\mathbf{X} 4$ indicates the independent variable - the quality of management, $\boldsymbol{X} 5$ - indicates the independent variable - the opportunity cost of reserves, $\boldsymbol{X} \mathbf{6}$ - indicates the independent variable - the income from other activities, $\boldsymbol{X} \mathbf{7}$ - indicates the independent variable - the index concentration and $\mathbf{X} \boldsymbol{8}$ - indicates the independent variable - the interest rate impact.

Table No. 1: The econometric results for the dependent variable MNI

\begin{tabular}{|c|c|c|c|c|c|c|}
\hline \multirow{3}{*}{ Independent variables } & \multicolumn{6}{|c|}{ Depended variable - Net InterestMargin } \\
\hline & \multicolumn{2}{|c|}{ Equation 1} & \multicolumn{2}{|c|}{ Equation 2} & \multicolumn{2}{|c|}{ Equation 3} \\
\hline & Coefficient & Prob. & Coefficient & Prob & Coefficien & Prob \\
\hline Constan & -0.00447 & 0.6981 & -0.00858 & 0.4712 & -0.00964 & 0.3995 \\
\hline Operating costs & 1.95563 & 0.0000 & 1.95626 & 0.0000 & 1.95265 & 0.0000 \\
\hline Attitude toward impad & 0.10914 & 0.1518 & 0.11791 & 0.1182 & 0.12773 & 0.0842 \\
\hline Credit/loan impac & -0.01293 & 0.0901 & -0.00478 & 0.5841 & -0.01626 & 0.0316 \\
\hline Quality management & -0.00052 & 0.4105 & -0.00045 & 0.4707 & -0.00018 & 0.7744 \\
\hline Opportunity costs of reserves & -0.08346 & 0.5578 & -0.05061 & 0.7216 & -0.04913 & 0.7206 \\
\hline $\begin{array}{l}\text { Incomes from other } \\
\text { activities. }\end{array}$ & 0.03035 & 0.0000 & 0.03251 & 0.0000 & 0.03284 & 0.0000 \\
\hline Concentration Indes & -0.00570 & 0.9014 & -0.02036 & 0.6488 & 0.00860 & 0.8467 \\
\hline Interest rate impac & -0.00828 & 0.4490 & -0.03887 & 0.1827 & -0.54683 & 0.0505 \\
\hline Prob.F-Statistic & 0.00000 & & 0.00000 & & 0.00000 & \\
\hline Adjusted R-Squas & 0.99796 & & 0.99802 & & 0.99812 & \\
\hline
\end{tabular}

The three equations above represent a coefficient of determination (adjusted R-square) very good level, ie $99.79 \%$ to equation $1,99.8 \%$ for equation 2 and $99.81 \%$ for equation 3 , which clarifies that the majority of fluctuation in the net 
interest margin is explained by the independent variables in this study. Regarding the test of significance, we see that prob. F-statistic is 0 , so, in general exists a connection between the dependent variable and independent variables. While regarding to the importance of each dependent variable individually assessed, we note that not all considered variables have statistic importance, so not all of them have strong ties with the net interest margin. From the general equation shown above we can reduce the constant parameter as it is not transmitted in the population $(-0.00447)$ if all the independent variables are 0 , the net interest margin cannot be negative.

The independent variable "operating expenses" in the regression equation represents a positive coefficient and it is statistically important as expected to be. An increase of this variable will lead to the increase of the net interest margin; this relationship complies also with the results obtained in the analysis of accounting analysis of net interest margin. For the three upper equations the ratio of the operating expenses with the total assets represents an estimated coefficient of 1.95, which is an indication that the increase of the bank's operating expenses with a unit will cause the latter to be transferred to bank customers, respectively with 1.95 times in the form of higher rates of interest for loans or lower for deposits.

Regarding the independent variable "attitude towards impact", it represents a positive coefficient. The relationship between the attitude toward impact and the net interest margin means that the banks anticipate that in the future they may experience losses from the granted loans and to be protected against this they increase their share capital but the capital financing is more expensive than the debt financing, so the banks, in order to compensate the cost of financing impose high interest margins. This coefficient for the above equations varies from 0109 for the first equation to 0118 for the second equation and 0128 for the third equation. An increase with one unit of the share capital will lead to increase of $12 \%$ of the net interest margin (equation 3).

The relationship between the net interest margin and credit impact in the regression equation is negative and the relationship between them is important for the equation 3 while some empirical studies have confirmed a positive relationship between variables. In the case of Albania, the coefficient -0016 (equation 3) shows that the increase with a unit of the problematic loans leads to a reduction of the net interest margin to 0.016 times. This result is explained by the fact that the increase in problematic loans in the banking system has made banks reduce the interest margins in order to reduce the potential problematic loans and to protect their incomes.

The quality management is the variable that affects minimally the fluctuation of the net interest margin in the case of the Albanian banking system, the coefficient - 0.00045 (equation 2) shows that the increase with a unit of the quality management will lower the net interest margin to 0.00045 units, so the relationship is negative as well as other empirical studies.

The explanatory variable opportunity cost of reserves is negatively correlated with the net interest margin, in the case of Albania the coefficient of this variable is -0083 (equation 1), which shows that its increase with one unit affects the net interest margin to 0.083 units. This result shows that the increase of the obligatory reserve at the central bank and the loss of profit from its keeping in the central bank are not transferred to bank customers through higher interest margins.

Income from other activities is a statistically important variable and its relationship with the net interest margin is positive, which means that the banks that have higher incomes from fees/commissions and not from their core activity tend to maintain higher interest margins to compensate their income. The increase of this variable with one unit affects the increase with 0033 (equation 3) units in the net interest margin.

The Independent variable - the concentration index in terms of loans, adversely affects the net interest margin in the first two equations and positively in the third equation. These results indicate that the increase the concentration of loans in the first two equations would reduce the net interest margin as the banks use higher concentrations to get specialized in the offered services and to reduce the net interest margin. While regarding the concentration of loans in the third equation, it is noted that the increase of the concentration of loans influences in the increase of the net interest margin with a coefficient of 0.009 times, so as many power the bank will have in lacing the interest rates so more will increase net interest margin.

Finally, the explanatory variable market impact, we see its impact to the dependent variable net interest margin, unlike the expectations, has a negative impact. An increase of the interest rates of treasury bills (equation 1), Euribor interest rates (equation 2) and libor interest rates (ekuacioni3) will lead to the reduction of the net interest margin. This conclusion comes as a result of the negative gaps of assets and liabilities according to the remained maturity in monthly periods from January 2005 to December 2014. 


\section{5- Conclusions}

1- $\quad$ The three studied equations represent a coefficient of determination (adjusted R-square) in very good levels, which clarifies that the majority of fluctuation of the net interest margin is explained by the independent variables taken into study.

2- $\quad$ The independent variable "operating expenses" in the regression equation represents a positive coefficient and it is statistically important. An increase of this variable will lead to the increase of the net interest margin.

3- $\quad$ Regarding the independent variable "attitude towards impact", it represents a positive coefficient. The relationship between the attitude towards impact and the net interest margin means that the banks anticipate that in the future they may experience losses from the granted loans and to be protected against this they increase their share capital but the capital financing is more expensive than the debt financing, so the banks, in order to compensate the cost of financing impose high interest margins.

4- $\quad$ The relationship between the net interest margin and credit impact in the regression equation is negative and the relationship between them is important for the equation 3 while some empirical studies have confirmed a positive relationship between variables.

5- $\quad$ The quality management is the variable that affects minimally the fluctuation of the net interest margin in the case of the Albanian banking system.

6- $\quad$ The explanatory variable opportunity cost of reserves is negatively correlated with the net interest margin in the case of Albania.

7- $\quad$ Income from other activities is a statistically important variable and its relationship with the net interest margin is positive.

8- $\quad$ The Independent variable - the concentration index in terms of loans, adversely affects the net interest margin in the first two equations and positively in the third equation.

9- $\quad$ The explanatory variable market impact, we see its impact to the dependent variable net interest margin, different from the expectations.

\section{References:}

[1] Angbazo, L. 1997. "Commercial Bank Net Interest Margins, Default Risk, Interest Rate Risk and Off-Balance Sheet Banking". Journal of Banking and Finance, 21, 55-87.

[2] Bank of Albania.

[3] Bernanke, Ben. 1983. "Nonmonetary effects of the financial crisis in the propagation of the Great Depression", American Economic Review, 73, 257-76.

[4] Berger, A. 1995. "The relationship between capital and earnings in banking". Journal of Money, Credit and Banking. Vol. 27.

[5] Brock, Philip and Liliana Rojas-Suárez. 2000. "Interest rate spreads in Latin America: Facts, Theories and Policy Recommendations". Inter-American Development Bank, 2000. (Why So High? Understanding Interest Rate Spreads in Latin America).

[6] Brock, Philip and Helmut Franken. 2002. "Bank Interest margins Meet Interest Rate Spreads: How Good is Balance Sheet Data for Analyzing the Cost of Financial Intermediation?" Mimeo Central Bank of Chile.

[7] Brock, Philip and Helmut Franken. 2003. "Measuring the Determinants of Average and Marginal Bank Interest Rate Spreads in Chile, 1994-2001". Mimeo Central Bank of Chile. • Claessens. Stijn, Asli Demirgüç-Kunt and Harry 
Huizinga. 1997. "How Does Foreign Entry Affect the Domestic Banking Market?" World Bank, Policy Research Department.

[8] Bozdo, A. (2012) "The role of Central Bank in Financial Institutions protection from global financiar crises through effective supervision)".

[9] Corvoisier, S. and R. Gropp. 2002. "Bank concentration and retail interest rates". Journal of Banking and Finance 26.

[10] Demirgüç-Kunt, Asli and Harry Huizinga. 1999. "Determinants of Commercial Bank Interest Margins and Profitability: Some International Evidence", The World Bank Economic Review, Vol. 13, No. 2, 379-408.

[11] Estrada, Dairo, Esteban Gómez and Inés Orozco. 2006. "Determinants of Interest Margins in Colombia". Borradores de Economia. No. 393.

[12] Hanson, James A. and Roberto de Rezende Rocha. 1986. "High Interest Rates, Spreads and the Cost of Intermediation: Two Studies". Industry and Finance. Series 18.

[13] Ho, Thomas S. Y and Anthony Saunders. 1981. "The determinants of bank interest margins: Theory and empirical evidence". Journal of Financial and Quantitative Analysis, Vol. XVI, Nr. 4, 1981.

[14] Kalluci, I (2010) "Net margin determinants of interest in the Albanian banking system".

[15] Kaufman, G. (1984) "Measuring and managing Interest rate Risk" 1984.

[16] Khawaja, Idrees and Musleh-ud Din. 2007. "Determinants of Interest Spreads in Pakistan", Pakistan Institute of Development Economic Working Papers, 22, 2007.

[17] Lerner E. M. 1981. "Discussion the determinants of bank interest margins: theory and empirical evidence". Journal of Financial and Quantitative Analysis, Vol. XVI, Nr. 4.

[18] Levine, Ross. 1997. "Financial Development and Economic Growth". Journal of Economic Literature, 35 (2).

[19] Liebeg, David and Markus S. Schwaiger. 2006. "Determinants of the Interest Rate Margins of Austrian Banks", Oesterreichische Nationalbank Financial Stability Report, 12 (2006), 104-116.

[20] Performance of Models-Based Capital Charges for Market Risk (BIS Sep. 1999).

[21] Principles for the management and supervision of interest Rate Risk July 2004 (BIS).

[22] Maudos, Joaqúin and Juan Fernández de Guevara. 2004. "Factors explaining the interest margin in the banking sectors of the European Union", Journal of Banking and Finance 28 (2004), 2259-2281.

[23] Naceur, B. Samy. 2003. "The determinants of the Tunisian Banking Industry profitability: Panel evidence". Universite Libre de Tunis, Department of Finance Working Paper 2003.

[24] Robinson, W. John. 2002. "Commercial bank interest rate spreads in Jamaica-Measurement, trends and prospects". Discussion Paper 2002.

[25] Saunders. A. and L. Schumacher. 2000. "The determinants of bank interest rate margins: an international study". Journal of International Money and Finance, 19.

[26] Saunders, A. \& Cornett, M. M. (2008), "Financial Institutions management" (Southern Illinois Universsity), McGraw 2008. 